\title{
EMPIRICAL ANALYSIS OF LONG MEMORY AND ASYMMETRY EFFECTS FOR THE EFFECTIVENESS OF FORECASTING VOLATILITY OF RETURNS ON THE COMMODITY MARKET BASED ON THE EXAMPLE OF GOLD AND SILVER
}

\section{Bogdan Włodarczyk', Ireneusz Miciuła²}

\footnotetext{
1 University of Warmia and Mazury in Olsztyn, Faculty of Economic Sciences, Department of Macroeconomics, Poland, ORCID: 0000-0002-8965-9957, bogdan.wlodarczyk@uwm.edu.pl;

2 University of Szczecin, Faculty of Economics and Management, Institute of Finance, Poland, ORCID: 0000-00033150-4490, ireneusz.miciula@usz.edu.pl (corresponding author).
}

\begin{abstract}
This paper presents an empirical analysis of the significance of the long memory and asymmetry effects for forecasting conditional volatility and market risk on the commodity market based on the example of gold and silver. The analysis involved testing a wide range of linear and non-linear GARCH-type models. The aim of studying dependencies between rates of return and volatility was to select the optimum model. In-sample and out-of-sample analysis indicated that volatility of returns on gold and silver is better described with non-linear volatility models accommodating long memory and asymmetry effects. In particular, the FIAPARCH model proved to be the best for estimating VaR forecasts for long and short trading positions. Also, this model generated the lowest number of violations of Basel II regulations at the confidence level of $99 \%$. Among the models studied, the FIAPARCH has the most elastic news impact curve, which translates into more possibilities to adjust to data. The results of the analyses suggest that within the period studied, the FIAPARCH model was the best predictive tool compared to the other models. This stems from the model's ability to satisfactorily capture the effects accompanying price volatility of precious metals, i.e. asymmetry and long memory. The FIAPARCH model produced the lowest number of VaR violations (lowest risk of the model) for all series, which means that it seems to be the most advantageous predictive model with respect to gold and silver from the point of view of financial institutions. Attention was also paid to the prevalence and significance of long memory and asymmetry effects, which should be taken into account when using GARCH-class models.
\end{abstract}

Keywords: Forecasting, price volatility, commodity market, risk management, long memory effect, GARCH models.

JEL Classification: C53, C58, E37, F37, F65, Q31.

APA Style Citation: Włodarczyk, B., \& Miciuła, I. (2020). Empirical Analysis of Long Memory and Asymmetry Effects for the Effectiveness of Forecasting Volatility of Returns on the Commodity Market Based on the Example of Gold and Silver. E\&M Economics and Management, 23(2), 126-143. https://doi.org/10.15240/tul/001/2020-2-009

\section{Introduction}

Risk management is one of the most dynamically developed areas in economic sciences. One of the main driving forces for this development has been the practical challenge resulting from increasing financial risk. Risk 
management is a process in which key role is played by risk measurement (Jajuga, 2016). Comparison of various forecasting models and selection of the best ones for particular markets is of key importance in many fields of economics and finance. Theoretic aspects concerning commodity markets very often concentrate on relations between changes in commodity prices and on the news impact on rates of return. However, up until now studies concerning conditional volatility of returns on commodity markets and market risk have been less comprehensive than those concerning conditions affecting prices and rates of return. Nevertheless, studies concerning market volatility are becoming increasingly popular due to the growth of market volatility itself and the significance of commodities as investment assets (Kang, 2013; Thuraisamy, 2013; Vivian, 2012). The growing interest also results from the fact that commodity rates of return have some empirically verifiable features such as non-normal distribution, asymmetry, structural breaks and fat tails (Aloui, 2010; Cheng, 2011). These features affect the accuracy of forecasts and therefore require some experiments with various volatility models. An important aspect in this context is the relation between risk and income, which constitutes theoretical and practical basis for assumptions in the process of risk management (Tarczyński \& Mojsiewicz, 2001). Risk management is a system of methods and measures, whose aim is to reach optimum decisions in order to mitigate the impact of risk on the functioning of a business entity. Detailed knowledge of the nature and scope of potential risk enables timely selection of preventive measures minimising its impact and consequences (Miciuła, 2015). Traditional approach to studying volatility on commodity markets focused mainly on the dynamics of volatility with respect to the price of a single commodity, or it referred to the spread of volatility over many commodities in time, which was tested with the use of standard volatility models. Latest studies attempt to collect various characteristics of volatility of particular commodities or their groups in order to define a set of tools allowing for more accurate forecasting of market volatility of prices and rates of return (Arouri, 2012a, b; Wei, 2010).

Studies on risk on commodity markets often use an approach based on the Value at Risk (VaR) measure. GARCH-class models are used for assessing forecasting models and estimating volatility. The best model for modelling volatility of rates of return would be a model which provides the most accurate VaR forecasts and estimates (Jajuga, 2000). This paper presents an attempt to assess the adequacy of linear and non-linear forecasting models with the use of varied assessment and forecasting criteria according to the $\mathrm{VaR}$ approach. The primary objective of the study was to verify the usefulness of GARCH-class models in modelling conditional price volatility (rates of return) and market risk (VaR) for gold and silver, given long memory and asymmetry effects. The phenomenon of long memory and asymmetry was accommodated not only with respect to volatility modelling, but also to increase the adequacy of VaR estimates and forecasts. The second objective of the study was to compare the predictive performance of GARCH-class models by conducting an out-of-sample analysis with the use of typical assessment criteria and the approach based on $\mathrm{VaR}$ for long and short trading positions. Economic utility of the results was assessed following the estimation of capital requirements based on Basel II standards with the use of $\mathrm{VaR}$ estimates derived from the GARCH-class models used for the analysis.

\section{Literature Review}

Literature is increasingly concerned with asymmetrical volatility of commodity markets. One of the most recent approaches attempts to combine various volatility characteristics within one model, which is the right approach for volatility modelling. Therefore, both symmetry and asymmetry of effects and long memory of commodity price volatility, individually and in particular groups, are subject to tests (Aloui, 2010; Wang, 2011). Defining long-range dependence within the scope of price volatility on commodity markets is of great importance form the point of view of forecasting, which, in turn, affects the valuation of assets, use of hedging, and risk management. For instance, Choi et al. came to the conclusion that onedimensional GARCH models accommodating the long memory effect of time series demonstrated forecasting abilities for volatility of commodity prices (crude oil and refined petroleum products) better than standard GARCH models (Choi, 2009). The impact of structural changes and long memory on 
commodity markets was also considered in the context of symmetry and asymmetry effects (Bekaert \& Wu, 2000). It was demonstrated that the phenomenon of long memory provides a better explanation of the volatility of rates of return on commodities than structural breaks. Therefore, parameter volatility modelling based on long memory of time series should contribute to the development of forecasting models allowing for more accurate forecasting (Aiolfi \& Timmermann, 2006), which will significantly contribute to improving investment analysis on commodity markets.

Gold, as one of the most valuable, alongside silver and platinum precious metals, has played a key role in the development of monetary systems in the world. Today, apart from the central bank's reserve assets, it is also an attractive investment form for individual investors and institutional investors (Moskal \& Zawadzka, 2014). The golden currency system of the nineteenth century was based on the full convertibility of money into gold according to certain criteria. Each currency had its own conversion factor, and the state guaranteed its full convertibility (Mikita, 2016). This system worked in its original premise until World War I. Although the gold currency system has ceased to exist, most central banks continue to hold foreign currency reserves in the form of gold in order to safeguard the value of the national currency. In the last few years, alternative investments have become of particular importance, with a negative correlation between returns on traditional assets such as shares and bonds. In the classification of alternative investments there are precious metals, among which special attention is paid to investments in gold. Such investments are often included in investment portfolios to diversify risks. The price of gold is based on relatively inflexible supply and demand reflecting the changing situation of the world economy (KasprzakCzelej, 2015). Factors influencing demand and supply of gold vary depending on the length of the period considered (Fig. 1). Gold prices in the short term are affected by US dollar buying power, interest rates, public sector, political events, information from the media. In the long term, they are global population growth, investment demand, gold output and a series of raw materials. It is suggested that shortterm factors determine the moment of entry or exit from gold investment, while long-term factors are important for strategic long-term investments (Mamcarz, 2015).

Gold prices are highly susceptible to the global economic situation. Any fluctuations in

\section{Fig. 1: Dynamics of gold prices in different currencies (currency per ounce)}

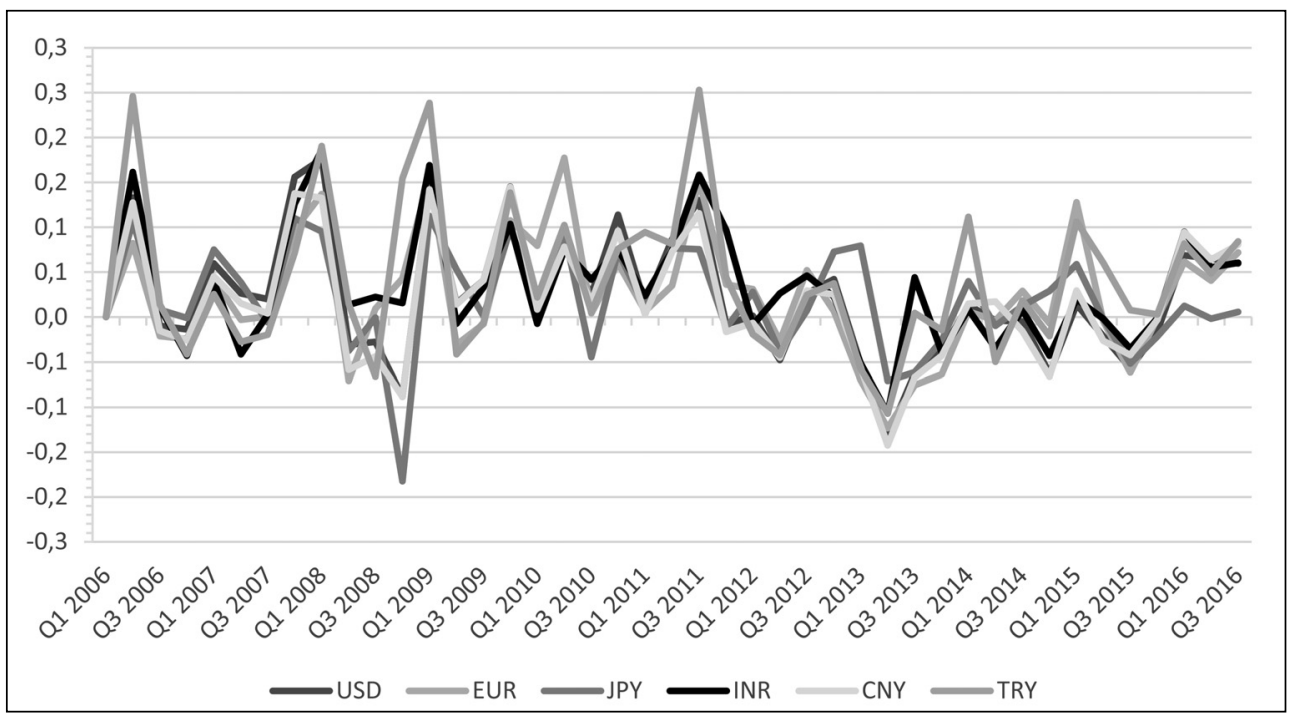


the above mentioned factors affect the price of this raw material in both short and long term. Gold prices expressed in key terms due to the specificity of this currency market show convergent directions of fluctuations. Both increases and decreases in prices in different currencies overlap, although some exceptions can be observed. The biggest decline in prices occurred in 2008. In response to the US economic crisis, the gold price has fallen the most in US dollars. Subsequently, the situation stabilized and gold prices were positive until 2013. In that year there was another sharp fall in prices for this commodity. Price growth of gold, although positive, has not returned to the level achieved before this year.

Precious metal markets are strongly correlated with each other. This means that when analyzing them, we have a better picture of the entire market. The fluctuations in silver prices are greater than fluctuations in the price of gold. If, in a given period, both markets are growing, the price of silver usually grows more, and when both markets fall, it is silver which loses stronger on value. Although the fundamental factors affecting the price of gold and silver are similar, some of them have different weight (Miciuła, 2018). The biggest difference between the two metals lies in the fact that silver is much more used by industry, which means that the silver market is more susceptible to the negative effects of the economic slowdown - especially in the context of falling orders from the industry. The price of silver does not increase clearly despite the demand that constantly exceeds supply, and various factors influence it. Silver has over 10,000 uses and its resources are limited. This causes fundamental differences in the characteristics of the silver market in relation to the gold market. This is important because there are many indications that negative real interest rates will be maintained in the coming years (inflation higher than interest rates on deposits), which will help further devalue global debt. In this environment metals are usually treated as protection against inflation and their price increases. In literature, gold investments are often referred to as "safe haven". It marks the direction of escape from the imminent threat. This concept is often used in financial markets. The most detailed definition of this concept in relation to financial assets was published in Baur and Lucea (2010). According to them a safe haven is an asset whose return is uncorrelated or negatively correlated to another asset in the portfolio during turbulence on the financial markets. The condition for an investment to play a safe haven is to generate positive returns, while other traditional investments record negative returns in the same period. Investigating whether a gold investment can serve as a safe haven for various financial instruments has been the subject of numerous studies. These features were often tested against stocks and bonds, less often against commodity investments. Baur and Lucey's (2010) study, based on daily data from 1995-2005, has shown that gold is a safe haven for stocks, but does not exhibit this feature in the US, UK and Germany bond markets. Moreover, gold can only function for 15 trading days, and then left in the portfolio will bring a loss to the investor. Baur and McDermott (2010) study the extension of this topic. Based on data from 1979-2009, a similar hypothesis has been verified for developed and developing countries. The results show that gold acts as both a hedge and a safe haven for most European equity markets and the US. These functions have not worked for countries such as Australia, Canada, Japan and the BRICS. It was also pointed out that at the height of the recent financial crisis, gold had met safe havens in the most developed markets, which did not work well in the Asian crisis. Most of the foreign studies are based on this methodology, testing the same hypothesis. An example may be the Bodington and Seetharam (2015) survey for gold investment in South African markets. The results show that for gold and gold investors investing in stocks and bonds, gold plays a protective role in the medium term. This did not work for international action. Portfolio analysis also showed that at the time of the stock market shock, the rate of return was positive. Moreover, the role of gold as a safe haven disappears after two days of session. Another work based on Baura and Lucey's methodology is Beckman, Berger and Chudai (2014). The study covered 18 independent markets with respect to regional indicators over the period 1970-2012. The analysis of yields confirmed the hypothesis, which allowed us to conclude that gold fulfills the conditions of both hedging and safe-haven investments in the examined markets depending on the specificity of the market. A similar test for the 
same hypothesis is Nielsen and Sørensen (2015). The authors analyzed not only shares and government bonds, but also corporate bonds, commodities and currency rates for 44 countries using the GARCH model. The results indicate that gold investments have played a safe haven role in the past 35 years for equity investments in the US and in many other countries, for government bonds in Europe and in Ireland, for highly profitable US corporate bonds and for all currencies tested. The results for the commodity market are ambiguous. It has also been observed that these conditions are not met after the recent financial crisis. In European countries, gold investment was a safe haven for the debt crisis in 2011. The above examples show a strong interest in investing in gold. It is of particular importance to test whether the investment satisfies the safe haven conditions and the hedging function in the context of the recent financial crisis. This is fully justified because the gold investment function is only verifiable at the large fall of most of the rates on the stock market. Most of the foreign studies confirm the fulfillment of these conditions. It turns out that gold meets the safe haven conditions by generating positive returns during turbulence on the financial markets, while traditional forms of investment, such as stocks or bonds, are losing. The research of this hypothesis concerning the Polish market is the study of Potrykus (2015). The author examined the correlation between the daily return on gold investment (expressed in dollars and PLN), the WIG index and the USD/ PLN exchange rate for the period January 2, 1995 - June 30, 2015. The results show that gold investment in dollars performs a diversifying function for investment in WIG. In turn, the investment in gold in zloty forms a safeguard for the entire Polish capital market. In addition, what is crucial from this point of view, gold investment fulfills the "safe haven" conditions in the Warsaw Stock Exchange, as indicated by Pearson's negative correlation coefficients. Investments in gold can therefore be profitable for investors who will benefit from favorable price increases and the resilience of this commodity to deteriorating economic conditions and crisis conditions. The lack of correlation with other financial assets may also be an argument for recognizing gold as a "safe haven".

When conducting research on the adequacy of the one-dimensional ARCH model for modelling precious metal markets, Mckenzie et al. did not observe any asymmetry effects (Mackenzie, 2009). Hammoudeh used the onedimensional model from the GARCH family to assess conditional volatility of prices of three metals (gold, silver, copper), eliminating the impact of distorting factors such as price shocks on the global crude oil market and the rates of return on three-month American treasury bonds (Hammoudeh, 2009). An analysis of particular characteristics of volatility, such as stability, asymmetrical reaction to good and bad news and constant, recurring elements, was also performed. It was found that conditional volatility of the prices of gold and silver is characterised by a higher stability and lower sensitivity to the leverage effect than the prices of copper. When studying volatility, Hammoudeh et al. performed a multi-dimensional analysis of correlation dependencies and interdependencies for four main precious metals, taking into consideration the geopolitical factor. An assessment of the impact of the results on portfolio decisions and hedging strategies was also conducted. Hedging, as a method of reducing, neutralising or protecting against risk of changes in prices of financial instruments or commodities with the use of derivative instruments, is subject to a number of current research studies described in the subject literature (Andersen et al., 2004; Wilhelmsson, 2006; Iwaszczuk \& Orłowska-Puzio, 2015). Conclusions drawn from the assessment of long- and shortterm dependencies point to the importance of information and historic volatility of prices (Hammoudeh, 2010). By combining the iterative cumulative sum of squares procedure with the GARCH $(1,1)$ model, Vivian et al. tried to specify whether there are structural breaks in spot return volatility of 28 commodities, including energy and precious metals. Limited evidence was found to confirm volatility breaks in commodity prices during the 2007-2010 crisis compared to the entire sample period, i.e. 1985-2010 (Vivian, 2012). Structural breaks in volatility were more clearly observable before the year 2007. Arouri et al. conducted an analysis of the potential of structural changes and the long memory effect with respect to rates of return and their volatility for four major precious metals. The study yielded strong evidence of long-range dependence in the case of daily returns and volatility processes for these metals. For most of the precious metals considered, the effect of dual long memory was 
best captured by the ARFIMA-FIGARCH model (Arouri, 2012a).

Wei et al. tried to connect findings following from the use of different models. The preliminary assumption was that the forecast superiority of a given GARCH model depends on the type of loss function used in the estimated volatility models. This assumption is debatable because the ability of a particular model to capture hidden characteristics of data is not the same in all cases and volatility features may also vary across different commodities. Given the fact that volatility forecasts are usually used to estimate the market risk for a single commodity or a portfolio of commodities, the accuracy of market risk forecasts constitutes the criterion for choosing the best volatility models. Therefore, a market risk measure, e.g. VaR, can be used in order to avoid the problem of multiple loss functions (Wei, 2010).

\section{Research Methodology and Sample}

The long memory and asymmetry of volatility effects are currently considered typical characteristics of returns on commodity markets. Asymmetry of volatility occurs when negative market shocks have a stronger impact on volatility than positive shocks. It appears mainly in periods of financial tensions, e.g. during financial crises. The long memory effect is a slow-paced phenomenon, i.e. slower than geometric progression of convergence of autocorrelation factors of market variable processes. Continuous aggregation of complex macroeconomic variables (demand, supply, industrial activity, monetary and regulatory policy) is at the very root of this effect. For instance, on the energy market, long memory with respect to the process of price formation may occur when price changes partially set off one another and are accompanied by a longterm effect of the original shock. The most obvious consequence of the existence of the long memory effect is the possibility to precisely forecast time series, which, in turn, contributes to reducing low information efficiency of markets (Elder, 2008). A high level of the long memory effect may indicate that the price of a particular commodity has long positive or negative deviations from equilibrium (Doman, 2009). The discrete model considered in the work describing the time series of simple return rates is given by the equation:

$$
r_{t}=\frac{X_{t}-X_{t-1}}{X_{t-1}}=\mu_{t}+\epsilon_{t}=\mu_{t}+z_{t} \sqrt{h_{t}}
$$

where:

$X_{t}-$ price at time $t$;

$\mu_{t}$ - conditional expected value of the rate of return at time $t$;

$h_{t}-$ conditional variance of the rate of return at time $t$;

$z_{t}-$ independent rests of the model with zero mean and unit variance.

The concept of model memory is used in the context of the autocorrelation function of the model residual squares $\left(\epsilon_{t}^{2}\right)$ or in the context of the influence of disturbances on the conditional variance forecasts in subsequent moments. The long memory refers to significant coefficients of autocorrelation of high rows of squares of model residues, and the occurrence of this effect affects a number of rates of return. The return rate model is given by the following system of equations:

$$
\begin{aligned}
& r_{t}=\mu+\varphi r_{t-1}+\epsilon_{t} \\
& \varepsilon_{t} \mid \delta_{t-1} \sim N\left(0, h_{t}\right)
\end{aligned}
$$

where:

$\delta_{t-1}-$ information available at time $t-1$.

The third equation, which will determine the form of a conditional variance model, is necessary to determine the full model.

The following four linear GARCH-class models were used for the purpose of comparison: GARCH, IGARCH, EGARCH and RiskMetrics. The following three non-linear GARCH models were also used: FIGARCH, FIAPARCH and $\mathrm{HYGARCH}$. The above models are widely referred to in the literature and their predictive performance and suitability were tested in a number of studies (Arouri, 2012b). Linear models constitute a reference point for testing persistence of volatility, asymmetry and infinitive persistence. The ARCH model can be generalized to the GARCH model (Generalized AutoRegressive Conditional Heteroskedasticity model, generalized $\mathrm{ARCH}$ ), which additionally introduces a direct dependence on previous $h_{t}$ values. The GARCH model $(p, q)$ is described in series:

$$
h_{t}=\alpha_{0}+\sum_{j=1}^{p} \beta_{j} h_{t-j}+\sum_{i=1}^{q} \alpha_{i} y_{t-i}^{2}
$$


where:

$h_{t}=h\left(y_{t-1}, y_{t-2}, \ldots, y_{t-p}, \alpha\right)$,

$y_{t}=\varepsilon_{t} h_{t}^{1 / 2}$

$\alpha_{o}>0, \alpha_{i}>=0, i>0$;

$\beta_{j}>=0$.

GARCH models are still very popular in modeling volatility of financial instruments. The main advantages of this type of models are efficiency in forecasting volatility, easy expansion and the ability to describe the most common characteristics of financial instruments (Furió \& Climent, 2013). The EGARCH model $(p, q)$ is described in series:

$$
\begin{aligned}
& \operatorname{lnh}_{t}=\alpha_{0}+\sum_{j=1}^{p} \beta_{j} \operatorname{lnh} h_{t-j}+ \\
& +\sum_{i=1}^{q} \alpha_{i}\left\{\theta z_{t-1}+\gamma\left[\left|z_{t-1}\right|-\right.\right. \\
& \left.\left.-E\left(\left|z_{t-1}\right|\right)\right]\right\}
\end{aligned}
$$

where:

$\Theta, \alpha_{o}$ - constantly;

$E\left(\left|z_{t-1}\right|\right)=\sqrt{\frac{2}{\pi}}-$ for normal distribution.

The EGARCH model is an extension of the standard GARCH model. Its application makes it possible to model the different impact of positive and negative rates of return on variance, or information asymmetry. Additionally, thanks to the logarithmic form, there is no need to impose restrictions on model parameters to ensure positive values of conditional variance, which facilitates model estimation, and the introduction of a standardized variable $\left(z_{t}\right)$ instead of the commonly used $\left(\varepsilon_{t}\right)$ one limits the impact of non-standard values on the conditional variance of the model (Lama, Jha, Paul, \& Gurung, 2015). In many cases, but mainly for the series of high frequency return rates, the estimated parameters of the $\mathrm{GARCH}$ model have such property:

$$
\sum_{i=1}^{q} \alpha_{i}+\sum_{j=1}^{p} \beta_{j} \approx 1
$$

This led to the exclusion of the Integrated GARCH (IGARCH) model class, which can be written using the following equation:

$$
[1-\emptyset(L)](1-L) \epsilon_{t}^{2}=\omega+[1-\beta(L)] v_{t}(7)
$$

where:

$\varnothing(L)$ - is a polynomial of the order of $m-1$, $(m=\max (p, q))$;

$L$ is a backshift operator: $L x_{t}=x_{t-1}, L^{m} x_{t}=x_{t-m}$.

For IGARCH $(1,1)$ we have the following form:

$$
h_{t}=\omega+\alpha_{1} \varepsilon_{t-1}^{2}+\left(1-\alpha_{1}\right) h_{t-1}
$$

Non-linear models were used for assessing long memory and asymmetry effects both separately and simultaneously. The most popular of the nonlinear models is the Fractionally IGARCH model, or FIGARCH $(p, d, q)$, which allows the description of long memory in a range of variations. It was introduced in 1996 by Baillie, Bollerslev and Mikkelsen (1996), and its equation is described by the following formula:

$$
[1-\emptyset(L)](1-L)^{d} \epsilon_{t}^{2}=\omega+[1-\beta(L)] v_{t}
$$

where:

$d \in(0,1)$;

all elements $1-\varnothing(L)=0$ and $1-\beta(L)=0$ lie outside the unit circle.

The determination of the autocorrelation function of the model residual squares in the case of FIGARCH is definitely more difficult than in the case of linear equivalents. This is done numerically, but in practice, modified recursive patterns are used to facilitate this (Tayefi \& Ramanathan, 2012).

Subsequently, evaluation criteria and the VaR approach were used to compare the outof-sample forecasting performance of these volatility models. Value at Risk $(\mathrm{VaR})$ is the most commonly used measure of risk. Due to the summary way of presenting a possible loss and ease of interpretation, this measure is applied by most financial institutions in practice (Assaf, 2009). According to the VaR formula, this is the expected value of the loss, and the probability of its achievement or exceeding is equal to the assumed level of significance. The formula for $\mathrm{VaR}$ is as follows:

$$
\rho\left(W_{t+1}<=W_{t}-V a R\right)=\alpha
$$

where:

$W_{t}$ - the value of capital at time $t$; $\rho$ - the probability of occurrence of an event.;

$\alpha$-assumed level of significance (1 - trust level). 
However, despite the widespread use of $\mathrm{VaR}$, it also has many shortcomings and measurement flaws. First of all, as a measure of risk, it does not meet the assumption of subadditivity, and the results depend to a large extent on the adopted estimation method (Szczerbak, 2017). Additionally, when the value at risk is exceeded, there is no information about the expected level.

Similar to many previous studies (Mohammadi, 2010; Wang, 2011), autoregressive process of order 1 was used to model the conditional mean and the GARCH $(1,1)$ class models were used to compare their predictive performance. Such specification was adopted on the basis of commonly used information criteria, i.e. the Akaike criterion (AIC) and the Schwarz criterion (BIC). Forecasting abilities are the key element of research on time series due to the importance of forecasts in the decisionmaking process (Miciuła, 2014). One model has better predictive abilities than other if the former provides forecasts whose degree of accuracy is higher (less mistakes). The following criteria were used to measure predictive abilities of seven GARCH-class models and to select the best one: mean absolute error (MAE) and mean absolute percentage error (MAPE). Competing models were used to forecast volatility of returns on gold and silver (out-of-sample) for a one-day and twenty-day period. The model which yielded lowest mean errors was considered the best in terms of predictive abilities. In the next stage of the research, the VaR risk measure for long and short trading positions in the $t$ period was used. The forecast daily conditional mean and standard deviation of returns on gold and silver, which was necessary to calculate the VaR, was established with the use of the GARCH model. The VaR was calculated for each series of returns for significance levels from $5 \%$ to $0.25 \%$. Then, the GARCH-VaR estimates were assessed by calculating the empirical failure rate for the left and right tails of the return distributions. The failure rate is understood as the number of times the commodity return series exceeds the estimated VaR (Jorion, 2007). If the failure rate is equal to the pre-specified level of significance, it may be concluded that the econometric model used for estimating the $\mathrm{VaR}$ is appropriate. This hypothesis was tested with the use of the Kupiec test (Kupiec, 1995).

According to Basel II Accord regulations, banks' VaR forecasts must be reported to competent supervisory authorities at the beginning of the day. At the end of the day they are compared to actual returns. In practice, banks' VaR forecasts are used to compute the amount of capital requirements (e.g. daily capital requirements) used as a buffer in the event of adverse market conditions. The Basel II Accord stipulates that the daily capital requirement must correspond to the highest estimated VaR from the previous day. Alternatively, the average $\mathrm{VaR}$ for the last 60 business days is estimated. This amount is additionally multiplied by the scaling factor, which depends on the quality of internal risk estimation models (i.e. the degree to which the qualitative norms stipulated in Basel II regulations with respect to risk management systems are met). The scaling factor is the sum of number 3 and the so-called additional factor. The additional factor ranges from 0 to 1 and it is related to the results of backtesting of VaR estimates. The daily capital requirement is the maximisation of the value of 60-day average VaR adjusted according to the scaling factor and the highest $\mathrm{VaR}$ estimate from the previous day. The data used in the study include spot prices and three-month futures prices for gold and silver. The data were sourced from the COMEX stock exchange and acquired via the Bloomberg service. The time span covers the period from February 20, 2000 to June 30, 2014. Price data sample covers the period from February 20, 2000 to December 31, 2012 and the out-of-sample period ranges from January 1, 2013 to June 30, 2014. Rates of return were calculated as logarithmic daily rates of return for two subsequent prices.

Tab. 1 and 2 presents descriptive statistics of daily returns respectively for investments in gold and silver. The first part includes mean rates of return $(0.049 \%$ for gold and $0.062 \%$ for silver), which were positive throughout the entire period under consideration. The standard deviation was higher for silver than for gold. It should be emphasised, however, that gold has a monetary value and its annual mining is low compared to the supply available, which contributes to a lower historical volatility. Generally, the analysis of the Sharpe ratio in the in-sample period indicates that gold was a better investment. Moreover, returns are positively skewed for gold and negatively skewed for silver. Therefore, these findings indicate that it is more likely to observe positive returns on gold and negative returns on silver. 


\begin{tabular}{|c|c|c|}
\hline & Spot prices & Futures prices \\
\hline \multicolumn{3}{|c|}{ Descriptive statistics } \\
\hline Mean $(\%)$ & 0.049 & 0.049 \\
\hline Standard deviation & 1.132 & 1.145 \\
\hline Sharpe ratio & 0.054 & 0.052 \\
\hline Skewness & 0.068 & 0.182 \\
\hline Kurtosis & 5.256 & 6.129 \\
\hline $\mathrm{JB}$ & $3,563.8^{* * *}$ & $4,491.1^{* * *}$ \\
\hline $\mathrm{Q}^{2}(10)$ & $497.26^{\star \star \star}$ & $315.03^{* * *}$ \\
\hline $\mathrm{ARCH}(4)$ & $49.923^{* * *}$ & $38.151^{* * *}$ \\
\hline \multicolumn{3}{|c|}{ Unit root tests } \\
\hline ADF & $-31.89^{* * *}$ & $-32.76^{* * *}$ \\
\hline KPSS & 0.211 & 0.189 \\
\hline Zivot-Andrews & $-55.823^{* * *}$ & $-25.413^{* * *}$ \\
\hline
\end{tabular}

Source: own

Note: JB, Q2(10) and ARCH(4) refer to statistics of Jarquea-Bera, Ljung-Box and Engle tests. ADF and KPSS are statistics of the Augmented Dickey-Fuller and Kwiatkowski-Phillips-Schmidt-Shin tests. The Zivot-Andrews test verified the null of unit root hypothesis. The ${ }^{\star \star *}$ symbol indicates the rejection of the null hypotheses at the level of significance of $1 \%$.

\section{Tab. 2: Descriptive statistics of time series of returns on silver and unit root tests}

\begin{tabular}{l|c|c} 
& Spot prices & Futures prices \\
\hline Mean (\%) & 0.062 & 0.062 \\
\hline Standard deviation & 1.967 & 1.897 \\
\hline Sharpe ratio & 0.043 & 0.044 \\
\hline Skewness & -0.417 & -0.782 \\
\hline Kurtosis & 7.993 & 7.582 \\
\hline JB & $8,623.7^{* * *}$ & $7,534.1^{* * *}$ \\
\hline$Q^{2}(10)$ & $279.35^{* * *}$ & $502.13^{* * *}$ \\
\hline ARCH(4) & $22.35^{* * *}$ & $38.772^{* * *}$ \\
\hline & Unit root tests & $-33.11^{* * *}$ \\
\hline ADF & $-31.46^{* * *}$ & 0.223 \\
\hline KPSS & 0.253 & $-58.244^{* * *}$
\end{tabular}

Source: own

Note: JB, Q2(10) and ARCH(4) refer to statistics of Jarquea-Bera, Ljung-Box and Engle tests. ADF and KPSS are statistics of the Augmented Dickey-Fuller and Kwiatkowski-Phillips-Schmidt-Shin tests. The Zivot-Andrews test verified the null of unit root hypothesis. The ${ }^{* * *}$ symbol indicates the rejection of the null hypotheses at the level of significance of $1 \%$. 


\begin{tabular}{|c|c|c|c|c|}
\hline & \multicolumn{2}{|c|}{ Gold } & \multicolumn{2}{|c|}{ Silver } \\
\hline & Spot & Futures & Spot & Futures \\
\hline \multicolumn{5}{|c|}{ GPH test } \\
\hline \multirow[t]{2}{*}{$m=T^{0.5}$} & -0.113 & -0.097 & -0.326 & -0.053 \\
\hline & $(0.269)$ & $(0.293)$ & $(0.717)$ & $(0.623)$ \\
\hline \multirow[t]{2}{*}{$m=T^{0.6}$} & -0.115 & -0.106 & -0.011 & -0.013 \\
\hline & $(0.063)$ & $(0.074)$ & $(0.739)$ & $(0.705)$ \\
\hline \multicolumn{5}{|c|}{ GPH test applied to squared returns } \\
\hline \multirow[t]{2}{*}{$m=T^{0.5}$} & 0.464 & 0.425 & 0.401 & 0.534 \\
\hline & $(0.000)$ & $(0.000)$ & $(0.000)$ & $(0.000)$ \\
\hline \multirow[t]{2}{*}{$m=T^{0.6}$} & 0.356 & 0.322 & 0.423 & 0.434 \\
\hline & $(0.000)$ & $(0.000)$ & $(0.000)$ & $(0.000)$ \\
\hline \multicolumn{5}{|c|}{ GSP test applied to returns } \\
\hline \multirow[t]{2}{*}{$m=T / 4$} & 0.007 & -0.012 & 0.002 & 0.008 \\
\hline & $(0.839)$ & $(0.722)$ & $(0.903)$ & $(0.783)$ \\
\hline \multirow[t]{2}{*}{$m=T / 8$} & -0.079 & -0.081 & -0.009 & -0.008 \\
\hline & $(0.069)$ & $(0.067)$ & $(0.789)$ & $(0.803)$ \\
\hline \multicolumn{5}{|c|}{ GSP test applied to squared returns } \\
\hline \multirow[t]{2}{*}{$m=T / 4$} & 0.218 & 0.201 & 0.163 & 0.197 \\
\hline & $(0.000)$ & $(0.000)$ & $(0.000)$ & $(0.000)$ \\
\hline \multirow[t]{2}{*}{$m=T / 8$} & 0.303 & 0.281 & 0.342 & 0.364 \\
\hline & $(0.000)$ & $(0.000)$ & $(0.000)$ & $(0.000)$ \\
\hline
\end{tabular}

Note: $m$ denotes the bandwidth used for the GPH and the GPS tests;

$T$ is the total number of observations;

the probability value ( $p$ value) is given in brackets.

All return series have a leptokurtic behaviour (a higher concentration around the mean value and thicker tails than in the case of normal distribution), which reflects excess kurtosis. The Jarque-Bera test confirmed deviation from normal distribution, while the Engle test for conditional heteroscedasticity and the Ljung-Box test present evidence for the occurrence of the $\mathrm{ARCH}$ effect (grouping of variances of return). Further unit root tests in the second part of the table: ADF, Kwiatkowski-Phillips-Schmidt-Shin test (KPSS) and Zivot-Andrews test (Zivot, 1992), confirmed stationarity of the studied time series for returns on gold and silver. Moreover, the Zivot-Andrews test is resistant to the occurrence of potential structural breaks. Given all the stylized facts exhibited by gold and silver return series, it was decided to use GARCHclass models to model conditional volatility.

\section{Empirical Analysis and Results}

The following tests were used to define the long memory effect for the conditional mean and variances of returns and squared returns on the metals under consideration: the statisticsbased log periodogram regression (GPH) test (Geweke, 1983) and the Gaussian semiparametric (GSP) test (Robinson, 1995). Tab. 3 presents the results of these tests. Weak evidence was found to support the occurrence 
of the long memory effect for the rates of return in the time series under consideration since, based on the above tests, it was impossible to reject the null hypothesis on the lack of longterm dependencies at the significance level of $5 \%$. For squared returns, both tests conclusively confirmed the hypothesis on the presence of the long memory effect at the significance level of $1 \%$. The tests eventually demonstrated that the forecasting approach based on $\mathrm{GARCH}$ class models, accommodating long memory effects, is appropriate.

A formula of conditional mean containing a constant term and an autoregressive term was used for each series of returns; the conditional variance was modelled by seven alternative GARCH models using empirically stylized facts of time series of returns such as persistence, non-linearity, asymmetry and long memory. These models were estimated with the use of Student- $t$ distributions and the Quasi-maximum Likelihood (QML) method. Tab. 4 and 5 present function parameter estimations and diagnostic tests applied to standardized residuals from the GARCH models.

What is most important is that there was a significant predictability of futures returns for the FIAPARCH model in the case of gold. While the coefficients referring to the GARCH elements were characterised by a high degree of

\section{Tab. 4: GARCH model parameters for gold}

\begin{tabular}{|c|c|c|c|c|c|c|c|c|c|c|c|c|c|c|}
\hline & \multicolumn{7}{|c|}{ Spot returns } & \multicolumn{7}{|c|}{ Futures returns } \\
\hline & GARCH & IGARCH & RM & EGARCH & FIGARCH & FIAPARCH & HYGARCH & GARCH & IGARCH & RM & EGARCH & FIGARCH & FIAPARCH & HYGARCH \\
\hline Const (m) & $\begin{array}{c}0.421^{* \star *} \\
(0.152)\end{array}$ & $\begin{array}{c}0.422^{\star \star \star} \\
(0.143)\end{array}$ & $\begin{array}{l}0.401^{\star *} \\
(0.134)\end{array}$ & $\begin{array}{c}0.429^{\star \star \star} \\
(0.128)\end{array}$ & $\begin{array}{c}0.414^{* * *} \\
(0.141)\end{array}$ & $\begin{array}{l}0.482^{\star \star \star} \\
(0.142)\end{array}$ & $\begin{array}{c}0.419^{\star \star \star} \\
(0.141)\end{array}$ & $\begin{array}{c}0.468^{\star \star \star} \\
(0.161)\end{array}$ & $\begin{array}{c}0.457^{\star \star \star} \\
(0.142)\end{array}$ & $\begin{array}{c}0.447^{\star \star \star} \\
(0.151)\end{array}$ & $\begin{array}{c}0.421^{\star \star \star} \\
(0.153)\end{array}$ & $\begin{array}{c}0.498^{\star \star \star} \\
(0.152)\end{array}$ & $\begin{array}{c}0.562^{\star \star *} \\
(0.158)\end{array}$ & $\begin{array}{c}0.485^{\star \star \star} \\
(0.151)\end{array}$ \\
\hline $\operatorname{AR}(1)$ & $\begin{array}{l}-0.026 \\
(0.016)\end{array}$ & $\begin{array}{l}-0.027 \\
(0.016)\end{array}$ & $\begin{array}{l}-0.025 \\
(0.017)\end{array}$ & $\begin{array}{l}-0.024 \\
(0.018)\end{array}$ & $\begin{array}{l}-0.025 \\
(0.018)\end{array}$ & $\begin{array}{l}-0.025 \\
(0.019)\end{array}$ & $\begin{array}{l}-0.026 \\
(0.016)\end{array}$ & $\begin{array}{l}-0.022 \\
(0.017)\end{array}$ & $\begin{array}{c}-0.022 \\
(0.017)\end{array}$ & $\begin{array}{l}-0.019 \\
(0.018)\end{array}$ & $\begin{array}{l}-0.024 \\
(0.017)\end{array}$ & $\begin{array}{l}-0.021 \\
(0.017)\end{array}$ & $\begin{array}{c}-0.028^{\star *} \\
(0.016)\end{array}$ & $\begin{array}{l}-0.024 \\
(0.017)\end{array}$ \\
\hline Const (p) & $\begin{array}{l}0.081^{* \star} \\
(0.034)\end{array}$ & $\begin{array}{c}0.085^{\star \star \star} \\
(0.044)\end{array}$ & & $\begin{array}{l}0.131^{\star \star \star} \\
(0.021)\end{array}$ & $\begin{array}{l}0.089^{\star \star} \\
(0.046)\end{array}$ & $\begin{array}{c}0.321 \\
(0.263)\end{array}$ & $\begin{array}{l}0.087^{\star *} \\
(0.039)\end{array}$ & $\begin{array}{l}0.081^{\star *} \\
(0.038)\end{array}$ & $\begin{array}{l}0.080^{\star \star} \\
(0.037)\end{array}$ & & $\begin{array}{l}0.121^{* \star *} \\
(0.024)\end{array}$ & $\begin{array}{c}0.672^{\star \star \star} \\
(0.236)\end{array}$ & $\begin{array}{c}0.453 \\
(0.341)\end{array}$ & $\begin{array}{c}0.084 \\
(0.061)\end{array}$ \\
\hline $\mathrm{ARCH}$ & $\begin{array}{l}0.058^{\star \star \star} \\
(0.010)\end{array}$ & $\begin{array}{c}0.055^{\star \star \star} \\
(0.008)\end{array}$ & 0.05 & $\begin{array}{l}0.088^{\star \star \star} \\
(0.012)\end{array}$ & $\begin{array}{c}0.032 \\
(0.072)\end{array}$ & $\begin{array}{c}-0.004 \\
(0.043)\end{array}$ & $\begin{array}{c}0.031 \\
(0.069)\end{array}$ & $\begin{array}{l}0.051^{\star \star \star} \\
(0.007)\end{array}$ & $\begin{array}{c}0.053^{\star * \star} \\
(0.007)\end{array}$ & 0.04 & $\begin{array}{c}0.082^{\star \star \star} \\
(0.011)\end{array}$ & $\begin{array}{c}0.312^{\star \star \star} \\
(0.048)\end{array}$ & $\begin{array}{l}-0.054 \\
(0.040)\end{array}$ & $\begin{array}{c}-0.022 \\
(0.067)\end{array}$ \\
\hline GARCH & $\begin{array}{c}0.937^{\star \star \star} \\
(0.008)\end{array}$ & $\begin{array}{c}0.938^{\star \star \star} \\
(0.018)\end{array}$ & 0.93 & $\begin{array}{l}0.943^{\star \star \star} \\
(0.003)\end{array}$ & $\begin{array}{c}0.935^{\star \star *} \\
(0.018)\end{array}$ & $\begin{array}{l}0.958^{\star \star \star} \\
(0.014)\end{array}$ & $\begin{array}{c}0.933^{\star \star \star} \\
(0.024)\end{array}$ & $\begin{array}{l}0.952^{* \star *} \\
(0.008)\end{array}$ & $\begin{array}{c}0.954^{\star \star \star} \\
(0.008)\end{array}$ & 0.93 & $\begin{array}{c}0.982^{\star \star *} \\
(0.001)\end{array}$ & $\begin{array}{c}0.667^{\star \star \star} \\
(0.058)\end{array}$ & $\begin{array}{c}0.963^{\star \star \star} \\
(0.012)\end{array}$ & $\begin{array}{c}0.954^{\star \star \star} \\
(0.028)\end{array}$ \\
\hline $\mathrm{EGARCH}(\delta)$ & & & & $\begin{array}{c}0.062^{\star \star \star} \\
(0.008)\end{array}$ & & & & & & & $\begin{array}{c}0.052^{\star \star \star} \\
(0.008)\end{array}$ & & & \\
\hline$d$ & & & & & $\begin{array}{c}0.468^{\star \star \star} \\
(0.103)\end{array}$ & $\begin{array}{c}0.536^{\star \star \star} \\
(0.156)\end{array}$ & $\begin{array}{c}0.479^{\star \star \star} \\
(0.055)\end{array}$ & & & & & $\begin{array}{c}0.378^{\star \star \star} \\
(0.048)\end{array}$ & $\begin{array}{l}0.424^{\star \star \star} \\
(0.062)\end{array}$ & $\begin{array}{c}0.436^{\star \star \star} \\
(0.002)\end{array}$ \\
\hline $\mathrm{ARCH}(\mathrm{V})$ & & & & & & $\begin{array}{c}-0.702^{* \star *} \\
(0.242)\end{array}$ & & & & & & & $\begin{array}{c}-0.689^{\star \star \star} \\
(0.201)\end{array}$ & \\
\hline $\operatorname{APARCH}(\delta)$ & & & & & & $\begin{array}{l}1.255^{\star \star \star} \\
(0.173)\end{array}$ & & & & & & & $\begin{array}{c}1.192 \\
(0.128)\end{array}$ & \\
\hline Student-t & $\begin{array}{l}3.788^{\star \star \star} \\
(0.298)\end{array}$ & $\begin{array}{c}3.839^{\star \star \star} \\
(0.259)\end{array}$ & $\begin{array}{c}4.589^{\star \star \star} \\
(0.278)\end{array}$ & $\begin{array}{c}4.248^{\star \star \star} \\
(0.345)\end{array}$ & $\begin{array}{l}3.842^{\star \star} \\
(0.255)\end{array}$ & $\begin{array}{c}4.352^{\star \star \star} \\
(0.361)\end{array}$ & $\begin{array}{l}3.789^{\star \star \star} \\
(0.310)\end{array}$ & $\begin{array}{c}3.958^{\star \star \star} \\
(0.346)\end{array}$ & $\begin{array}{c}3.9219^{\star \star \star} \\
(0.286)\end{array}$ & $\begin{array}{c}4.675^{\star \star \star} \\
(0.291)\end{array}$ & $\begin{array}{c}4.212^{\star \star \star} \\
(0.351)\end{array}$ & $\begin{array}{c}3.909^{\star \star \star} \\
(0.292)\end{array}$ & $\begin{array}{c}4.382^{\star \star \star} \\
(0.387)\end{array}$ & $\begin{array}{c}3.948^{\star \star \star} \\
(0.362)\end{array}$ \\
\hline $\log (L)$ & 9331.23 & 9331.52 & 9322.43 & 9271.14 & 9332.78 & 9353.44 & 9328.99 & 9181.12 & 9186.17 & 9158.33 & 9121.12 & 9181.77 & 9202.21 & 9182.41 \\
\hline \multicolumn{15}{|c|}{ Tests } \\
\hline AIC & -6.468 & -6.469 & -6.461 & -6.425 & -6.468 & -6.480 & -6.467 & -6.366 & -6.367 & -6.359 & -6.322 & -6.366 & -6.377 & -6.365 \\
\hline $\mathrm{BIC}$ & -6.460 & -6.463 & -6.459 & -6.412 & -6.457 & -6.475 & -6.454 & -6.349 & -6.352 & -6.349 & -6.298 & -6.346 & -6.353 & -6.343 \\
\hline $\mathrm{ARCH}(5)$ & $\begin{array}{l}1.290 \\
(0.15)\end{array}$ & $\begin{array}{l}1.290 \\
(0.15)\end{array}$ & $\begin{array}{c}2.162 \\
(0.048)\end{array}$ & $\begin{array}{c}1.678 \\
(0.153)\end{array}$ & $\begin{array}{c}1.285 \\
(0.158)\end{array}$ & $\begin{array}{l}1.623 \\
(0.01)\end{array}$ & $\begin{array}{c}1.278 \\
(0.158)\end{array}$ & $\begin{array}{l}1.758 \\
(0.11)\end{array}$ & $\begin{array}{c}1.78 \\
(0.11)\end{array}$ & $\begin{array}{c}0.678 \\
(0.637)\end{array}$ & $\begin{array}{c}0.887 \\
(0.452)\end{array}$ & $\begin{array}{l}1.183 \\
(0.21)\end{array}$ & $\begin{array}{l}1.263 \\
(0.12)\end{array}$ & $\begin{array}{l}1.162 \\
(0.19)\end{array}$ \\
\hline Q2(10) & $\begin{array}{l}15.332 \\
(0.09)\end{array}$ & $\begin{array}{l}14.87 \\
(0.09)\end{array}$ & $\begin{array}{l}12.21 \\
(0.09)\end{array}$ & $\begin{array}{c}9.821 \\
(0.264)\end{array}$ & $\begin{array}{l}15.22 \\
(0.08)\end{array}$ & $\begin{array}{l}12.12 \\
(0.19)\end{array}$ & $\begin{array}{l}14.93 \\
(0.08)\end{array}$ & $\begin{array}{l}10.15 \\
(0.17)\end{array}$ & $\begin{array}{l}10.18 \\
(0.17)\end{array}$ & $\begin{array}{c}5.342 \\
(0.854)\end{array}$ & $\begin{array}{c}5.879 \\
(0.701)\end{array}$ & $\begin{array}{l}13.815 \\
(0.08)\end{array}$ & $\begin{array}{l}17.36 \\
(0.03)\end{array}$ & $\begin{array}{l}13.702 \\
(0.08)\end{array}$ \\
\hline$Q(10)$ & $\begin{array}{c}13.127 \\
(0.17)\end{array}$ & $\begin{array}{c}13.131 \\
(0.17)\end{array}$ & $\begin{array}{l}11.876 \\
(0.18)\end{array}$ & $\begin{array}{c}13.217 \\
(0.17)\end{array}$ & $\begin{array}{c}13.876 \\
(0.11)\end{array}$ & $\begin{array}{c}10.945 \\
(0.31)\end{array}$ & $\begin{array}{l}13.487 \\
(0.14)\end{array}$ & $\begin{array}{c}13.988 \\
(0.11)\end{array}$ & $\begin{array}{l}13.887 \\
(0.11)\end{array}$ & $\begin{array}{l}11.657 \\
(0.17)\end{array}$ & $\begin{array}{l}16.789 \\
(0.05)\end{array}$ & $\begin{array}{c}13.725 \\
(0.11)\end{array}$ & $\begin{array}{l}12.622 \\
(0.12)\end{array}$ & $\begin{array}{l}13.371 \\
(0.11)\end{array}$ \\
\hline$J B$ & $\begin{array}{l}2756 \\
(0.00)\end{array}$ & $\begin{array}{l}2837 \\
(0.00)\end{array}$ & $\begin{array}{l}4977 \\
(0.00)\end{array}$ & $\begin{array}{l}2124 \\
(0.00)\end{array}$ & $\begin{array}{c}3898 \\
(0.00)\end{array}$ & $\begin{array}{l}3697 \\
(0.00)\end{array}$ & $\begin{array}{l}4105 \\
(0.00)\end{array}$ & $\begin{array}{l}6856 \\
(0.00)\end{array}$ & $\begin{array}{c}6632 \\
(0.00)\end{array}$ & $\begin{array}{l}9798 \\
(0.00)\end{array}$ & $\begin{array}{l}7623 \\
(0.00)\end{array}$ & $\begin{array}{l}7812 \\
(0.00)\end{array}$ & $\begin{array}{l}7879 \\
(0.00)\end{array}$ & $\begin{array}{l}7377 \\
(0.00)\end{array}$ \\
\hline
\end{tabular}

Source: own

Note: The probability value ( $p$-value) is given in brackets. The * ${ }^{* *}$ and ${ }^{* * *}$ symbols refer to levels of significance of $10 \%$, $5 \%$ and $1 \%$ respectively. 


\section{Tab. 5: GARCH model parameters for silver}

\begin{tabular}{|c|c|c|c|c|c|c|c|c|c|c|c|c|c|c|}
\hline & \multicolumn{7}{|c|}{ Spot returns } & \multicolumn{7}{|c|}{ Futures returns } \\
\hline & GARCH & IGARCH & RM & EGARCH & FIGARCH & FIAPARCH & HYGARCH & GARCH & IGARCH & $\mathrm{RM}$ & EGARCH & FIGARCH & FIAPARCH & HYGARCH \\
\hline Const (m) & $\begin{array}{c}0.231 \\
(0.210)\end{array}$ & $\begin{array}{c}0.228 \\
(0.208)\end{array}$ & $\begin{array}{c}0.192 \\
(0.213)\end{array}$ & $\begin{array}{l}0.261^{\star \star} \\
(0.118)\end{array}$ & $\begin{array}{c}0.252 \\
(0.204)\end{array}$ & $\begin{array}{l}0.363^{*} \\
(0.201)\end{array}$ & $\begin{array}{c}0.241 \\
(0.202)\end{array}$ & $\begin{array}{r}0.631^{\star \star \star} \\
(0.218)\end{array}$ & $\begin{array}{c}0.728^{\star \star \star} \\
(0.219)\end{array}$ & $\begin{array}{l}0.548^{\star *} \\
(0.233)\end{array}$ & $\begin{array}{c}0.687^{\star \star \star} \\
(0.213)\end{array}$ & $\begin{array}{c}0.628^{\star \star *} \\
(0.213)\end{array}$ & $\begin{array}{c}0.721^{\star \star \star *} \\
(0.228)\end{array}$ & $\begin{array}{l}0.633^{\star \star *} \\
(0.228)\end{array}$ \\
\hline $\operatorname{AR}(1)$ & $\begin{array}{l}0.078^{* \star *} \\
(0.017)\end{array}$ & $\begin{array}{c}-0.078^{\star \star \star} \\
(0.017)\end{array}$ & $\begin{array}{c}-0.077^{\star \star \star} \\
(0.016)\end{array}$ & $\begin{array}{c}-0.083^{\star \star \star} \\
(0.017)\end{array}$ & $\begin{array}{c}-0.083^{\star \star \star} \\
(0.017)\end{array}$ & $\begin{array}{c}-0.088^{\star \star \star} \\
(0.018)\end{array}$ & $\begin{array}{c}-0.084^{* \star *} \\
(0.018)\end{array}$ & $\begin{array}{l}-0.026^{*} \\
(0.013)\end{array}$ & $\begin{array}{l}-0.026^{*} \\
(0.013)\end{array}$ & $\begin{array}{l}-0.025 \\
(0.013)\end{array}$ & $\begin{array}{l}-0.024^{\star} \\
(0.018)\end{array}$ & $\begin{array}{l}-0.033^{\star} \\
(0.017)\end{array}$ & $\begin{array}{l}-0.036^{*} \\
(0.017)\end{array}$ & $\begin{array}{l}-0.033^{\star *} \\
(0.017)\end{array}$ \\
\hline Const (p) & $\begin{array}{l}0.084^{\star *} \\
(0.048)\end{array}$ & $\begin{array}{l}0.016^{\star *} \\
(0.003)\end{array}$ & & $\begin{array}{l}0.126^{\star \star \star *} \\
(0.022)\end{array}$ & $\begin{array}{l}0.068^{\star *} \\
(0.043)\end{array}$ & $\begin{array}{c}0.042 \\
(0.041)\end{array}$ & $\begin{array}{l}0.065^{\star \star} \\
(0.038)\end{array}$ & $\begin{array}{l}0.079^{* *} \\
(0.042)\end{array}$ & $\begin{array}{l}0.078^{\star \star} \\
(0.028)\end{array}$ & & $\begin{array}{c}0.112^{\star \star \star} \\
(0.020)\end{array}$ & $\begin{array}{l}0.073^{* \star} \\
(0.031)\end{array}$ & $\begin{array}{c}0.018 \\
(0.021)\end{array}$ & $\begin{array}{l}0.079^{* *} \\
(0.034)\end{array}$ \\
\hline $\mathrm{ARCH}$ & $\begin{array}{c}0.048^{\star \star *} \\
(0.011)\end{array}$ & $\begin{array}{c}0.049^{\star * *} \\
(0.011)\end{array}$ & 0.05 & $\begin{array}{c}0.101^{* * *} \\
(0.012)\end{array}$ & $\begin{array}{c}0.073 \\
(0.048)\end{array}$ & $\begin{array}{c}0.043 \\
(0.062)\end{array}$ & $\begin{array}{c}0.075 \\
(0.077)\end{array}$ & $\begin{array}{c}0.028^{\star * *} \\
(0.006)\end{array}$ & $\begin{array}{c}0.027^{\star \star \star} \\
(0.007)\end{array}$ & 0.03 & $\begin{array}{c}0.087^{\star \star \star} \\
(0.015)\end{array}$ & $\begin{array}{c}0.069 \\
(0.043)\end{array}$ & $\begin{array}{c}0.081 \\
(0.074)\end{array}$ & $\begin{array}{c}0.065 \\
(0.041)\end{array}$ \\
\hline GARCH & $\begin{array}{c}0.872^{\star \star \star} \\
(0.011)\end{array}$ & $\begin{array}{c}0.913^{\star \star *} \\
(0.011)\end{array}$ & 0.87 & $\begin{array}{c}0.969^{\star \star \star} \\
(0.003)\end{array}$ & $\begin{array}{c}0.966^{\star \star \star} \\
(0.018)\end{array}$ & $\begin{array}{c}0.961^{* \star \star} \\
(0.017)\end{array}$ & $\begin{array}{c}0.963^{\star \star \star} \\
(0.031)\end{array}$ & $\begin{array}{c}0.959^{\star \star *} \\
(0.007)\end{array}$ & $\begin{array}{c}0.952^{\star \star \star} \\
(0.07)\end{array}$ & 0.95 & $\begin{array}{c}0.966^{\star \star \star} \\
(0.003)\end{array}$ & $\begin{array}{c}0.958^{* \star *} \\
(0.012)\end{array}$ & $\begin{array}{c}0.943^{\star \star \star} \\
(0.032)\end{array}$ & $\begin{array}{l}0.961^{\star \star \star} \\
(0.010)\end{array}$ \\
\hline $\mathrm{EGARCH}(\delta)$ & & & & $\begin{array}{c}0.0480^{\star \star *} \\
(0.008)\end{array}$ & & & & & & & $\begin{array}{c}0.032^{\star \star \star} \\
(0.007)\end{array}$ & & & \\
\hline$d$ & & & & & $\begin{array}{l}0.499^{\star \star \star} \\
(0.038)\end{array}$ & $\begin{array}{c}0.493^{\star \star \star} \\
(0.031)\end{array}$ & $\begin{array}{c}0.463^{* \star *} \\
(0.091)\end{array}$ & & & & & $\begin{array}{c}0.482^{\star \star \star} \\
(0.031)\end{array}$ & $\begin{array}{c}0.479^{\star * \star} \\
(0.033)\end{array}$ & $\begin{array}{l}0.487^{\star \star \star} \\
(0.031)\end{array}$ \\
\hline APARCH(Y) & & & & & & $\begin{array}{c}-0.421^{\star * \star} \\
(0.187)\end{array}$ & & & & & & & $\begin{array}{c}-0.284^{\star * \star} \\
(0.121)\end{array}$ & \\
\hline $\operatorname{APARCH}(\bar{\delta})$ & & & & & & $\begin{array}{l}1.699^{\star * \star} \\
(0.217)\end{array}$ & & & & & & & $\begin{array}{c}1.974^{\star \star \star} \\
(0.118)\end{array}$ & \\
\hline Student-t & $\begin{array}{c}4.387^{\star \star \star} \\
(0.278)\end{array}$ & $\begin{array}{c}4.430^{\star * \star} \\
(0.214)\end{array}$ & $\begin{array}{c}5.143^{* \star \star} \\
(0.214)\end{array}$ & $\begin{array}{c}4.386^{\star \star *} \\
(0.271)\end{array}$ & $\begin{array}{c}4.467^{\star \star \star} \\
(0.230)\end{array}$ & $\begin{array}{c}4.543^{* \star \star} \\
(0.274)\end{array}$ & $\begin{array}{c}4.538^{* \star *} \\
(0.301)\end{array}$ & $\begin{array}{r}4.231^{\star \star *} \\
(0.350)\end{array}$ & $\begin{array}{c}4.203^{\star \star \star} \\
(0.283)\end{array}$ & $\begin{array}{r}4.966^{\star * *} \\
(0.316)\end{array}$ & $\begin{array}{c}4.360^{\star \star \star} \\
(0.368)\end{array}$ & $\begin{array}{c}4.237^{\star \star \star} \\
(0.292)\end{array}$ & $\begin{array}{c}4.456^{* \star \star} \\
(0.357)\end{array}$ & $\begin{array}{c}4.312^{\star \star \star} \\
(0.357)\end{array}$ \\
\hline $\log (L)$ & 7781.46 & 7781.45 & 7770.52 & 7732.72 & 7786.19 & 7801.34 & 7768.09 & 7872.53 & 7871.51 & 7854.30 & 7828.19 & 7875.46 & 7884.45 & 7873.53 \\
\hline \multicolumn{15}{|c|}{ Tests } \\
\hline AlC & -5.362 & -5.363 & -5.356 & -5.327 & -5.365 & -5.372 & -5.364 & -5.425 & -5.426 & -5.418 & -5.483 & -5.426 & -5.437 & -5.424 \\
\hline $\mathrm{BIC}$ & -5.571 & -5.574 & -5.572 & -5.532 & -5.572 & -5.575 & -5.569 & -5.634 & -5.637 & -5.629 & -5.585 & -5.634 & -5.638 & -5.631 \\
\hline $\mathrm{ARCH}(5)$ & $\begin{array}{l}1.287 \\
(0.08)\end{array}$ & $\begin{array}{l}1.288 \\
(0.08)\end{array}$ & $\begin{array}{l}3.748 \\
(0.03)\end{array}$ & $\begin{array}{c}1.908 \\
(0.112)\end{array}$ & $\begin{array}{l}1.257 \\
(0.21)\end{array}$ & $\begin{array}{l}1.282 \\
(0.10)\end{array}$ & $\begin{array}{l}1.256 \\
(0.15)\end{array}$ & $\begin{array}{l}1.132 \\
(0.36)\end{array}$ & $\begin{array}{l}1.131 \\
(0.36)\end{array}$ & $\begin{array}{l}1.135 \\
(0.36)\end{array}$ & $\begin{array}{l}1.135 \\
(0.37)\end{array}$ & $\begin{array}{l}1.179 \\
(0.28)\end{array}$ & $\begin{array}{l}1.138 \\
(0.34)\end{array}$ & $\begin{array}{l}1.136 \\
(0.34)\end{array}$ \\
\hline Q2(10) & $\begin{array}{c}7.04 \\
(0.65)\end{array}$ & $\begin{array}{c}7.12 \\
(0.63)\end{array}$ & $\begin{array}{l}24.37 \\
(0.05)\end{array}$ & $\begin{array}{c}14.87 \\
(0.078)\end{array}$ & $\begin{array}{c}16.49 \\
(0.078)\end{array}$ & $\begin{array}{c}8.52 \\
(0.63)\end{array}$ & $\begin{array}{c}7.16 \\
(0.75)\end{array}$ & $\begin{array}{c}9.59 \\
(0.32)\end{array}$ & $\begin{array}{c}9.58 \\
(0.32)\end{array}$ & $\begin{array}{c}9.71 \\
(0.32)\end{array}$ & $\begin{array}{c}9.76 \\
(0.32)\end{array}$ & $\begin{array}{c}9.70 \\
(0.35)\end{array}$ & $\begin{array}{l}11.32 \\
(0.34)\end{array}$ & $\begin{array}{c}9.72 \\
(0.38)\end{array}$ \\
\hline $\mathrm{Q}(10)$ & $\begin{array}{l}7.341 \\
(0.75)\end{array}$ & $\begin{array}{l}7.104 \\
(0.65)\end{array}$ & $\begin{array}{l}8.185 \\
(0.66)\end{array}$ & $\begin{array}{l}11.417 \\
(0.34)\end{array}$ & $\begin{array}{l}8.259 \\
(0.67)\end{array}$ & $\begin{array}{l}10.007 \\
(0.56)\end{array}$ & $\begin{array}{l}8.204 \\
(0.61)\end{array}$ & $\begin{array}{l}8.032 \\
(0.54)\end{array}$ & $\begin{array}{l}8.043 \\
(0.54)\end{array}$ & $\begin{array}{l}8.514 \\
(0.58)\end{array}$ & $\begin{array}{l}12.054 \\
(0.245)\end{array}$ & $\begin{array}{c}8.760 \\
(0.514)\end{array}$ & $\begin{array}{c}9.412 \\
(0.427)\end{array}$ & $\begin{array}{c}8.622 \\
(0.521)\end{array}$ \\
\hline $\mathrm{JB}$ & $\begin{array}{c}1288 \\
(0.00)\end{array}$ & $\begin{array}{c}1328 \\
(0.00)\end{array}$ & $\begin{array}{c}1226 \\
(0.00)\end{array}$ & $\begin{array}{c}2932 \\
(0.00)\end{array}$ & $\begin{array}{c}1623 \\
(0.00)\end{array}$ & $\begin{array}{c}1643 \\
(0.00)\end{array}$ & $\begin{array}{c}1514 \\
(0.00)\end{array}$ & $\begin{array}{c}2152 \\
(0.00)\end{array}$ & $\begin{array}{c}2212 \\
(0.00)\end{array}$ & $\begin{array}{c}1801 \\
(0.00)\end{array}$ & $\begin{array}{c}1915 \\
(0.00)\end{array}$ & $\begin{array}{c}1814 \\
(0.00)\end{array}$ & $\begin{array}{c}1569 \\
(0.00)\end{array}$ & $\begin{array}{c}1784 \\
(0.00)\end{array}$ \\
\hline
\end{tabular}

Source: own

Note: The probability value ( $p$-value) is given in brackets. The ${ }^{*},{ }^{* *}$ and ${ }^{* * *}$ symbols refer to levels of significance of $10 \%$, $5 \%$ and $1 \%$ respectively.

significance, the coefficients associated with the $\mathrm{ARCH}$ elements were statistically insignificant in five out of fourteen cases. The low value of ARCH coefficients may signify that the volatility of gold returns does not present violent reaction over time. The leverage parameter $(\delta)$ of the EGARCH model is statistically significant and its value is positive, which means that positive price shocks in the case of gold have a bigger impact on conditional volatility than negative shocks. This observation is fully consistent with parameters from the FIAPARCH models, with APARCH parameters $(\gamma)$ being negative and statistically significant. Given the Log(L), AIC and
BIC criteria, the FIAPARCH model is best suited for time series of gold spot and futures returns.

The results for silver are similar to those for gold. However, the evidence of predictive abilities for silver is more convincing. This results from the fact that gold is characterised by a considerably lower volatility than silver. In most cases silver spot and futures returns demonstrated a significant negative relationship with returns delayed by one period. This may be indicative of mean-reverting corrections of silver prices in the period studied. As with gold, the FIAPARCH model was selected as best suited for modelling silver volatility. 
Comparison of the forecasting quality of the studied volatility models for gold and silver (in-sample and out-of-sample period)

\begin{tabular}{|c|c|c|c|c|c|}
\hline \multirow{2}{*}{ Model } & \multirow{2}{*}{ Criterion } & \multicolumn{2}{|c|}{ Gold } & \multicolumn{2}{|c|}{ Silver } \\
\hline & & Spot & Futures & Spot & Futures \\
\hline \multicolumn{6}{|c|}{ One-day forecast } \\
\hline \multirow{2}{*}{ GARCH } & I & 0.462 & 0.474 & 0.321 & 2.329 \\
\hline & II & 0.709 & 0.766 & 14.38 & 0.960 \\
\hline \multirow{2}{*}{ IGARCH } & I & 0.422 & 0.492 & 0.324 & 2.316 \\
\hline & II & 0.712 & 0.747 & 14.83 & 0.958 \\
\hline \multirow{2}{*}{ RM } & I & 0.471 & 0.521 & 0.377 & 2.168 \\
\hline & II & 0.766 & 0.789 & 17.45 & 0.978 \\
\hline \multirow{2}{*}{ EGARCH } & I & 0.395 & 0.496 & $\underline{0.319}$ & 2.327 \\
\hline & II & 0.732 & 0.804 & 13.19 & 0.954 \\
\hline \multirow{2}{*}{ FIGARCH } & 1 & 0.341 & $\underline{0.463}$ & 0.372 & 2.303 \\
\hline & II & 0.688 & $\underline{0.724}$ & 18.24 & 0.953 \\
\hline \multirow{2}{*}{ FIAPARCH } & I & 0.396 & 0.474 & 0.349 & 1.897 \\
\hline & II & 0.715 & 0.768 & 15.78 & $\underline{0.899}$ \\
\hline \multirow{2}{*}{ HYGARCH } & 1 & $\underline{0.282}$ & 0.484 & 0.328 & 2.308 \\
\hline & II & $\underline{0.647}$ & 0.759 & 15.74 & 0.957 \\
\hline \multicolumn{6}{|c|}{ Twenty-day forecast } \\
\hline \multirow{2}{*}{ GARCH } & 1 & 0.275 & 0.339 & 0.372 & 0.489 \\
\hline & II & 32.24 & 39.52 & 75.16 & 81.32 \\
\hline \multirow{2}{*}{ IGARCH } & I & 0.276 & 0.358 & 0.369 & 0.596 \\
\hline & II & 31.36 & 40.24 & 72.41 & 89.23 \\
\hline \multirow{2}{*}{ RM } & 1 & 0.273 & 0.412 & 0.332 & 0.601 \\
\hline & II & 29.75 & 39.48 & 79.13 & 90.82 \\
\hline \multirow{2}{*}{ EGARCH } & I & 0.276 & 0.425 & $\underline{0.328}$ & 0.476 \\
\hline & II & 48.42 & 43.24 & $\underline{67.15}$ & 85.37 \\
\hline \multirow{2}{*}{ FIGARCH } & 1 & 0.278 & 0.329 & 0.329 & 0.428 \\
\hline & II & 41.23 & 40.13 & 69.78 & 88.81 \\
\hline \multirow{2}{*}{ FIAPARCH } & I & $\underline{0.214}$ & $\underline{0.314}$ & 0.335 & $\underline{0.415}$ \\
\hline & II & $\underline{27.63}$ & $\underline{32.61}$ & 69.46 & $\underline{77.34}$ \\
\hline \multirow{2}{*}{ HYGARCH } & I & 0.279 & 0.335 & 0.336 & 0.512 \\
\hline & II & 33.74 & 42.49 & 68.47 & 78.53 \\
\hline
\end{tabular}

Assessment criteria: I for MAE and II for MAPE. The underlined values refer to the best model.

With the one-day time horizon, none of the models considerably outclassed the remaining ones. The EGARCH, FIAPARCH, HYGARCH and FIGARCH models were chosen as suitable for forecasts with respect to spot returns for both precious metals. In terms of futures returns, the 
FIAPARCH model was selected for silver and the FIGARCH model was selected for gold. Generally, non-linear GARCH-class models, which were able to capture two significant effects accompanying the volatility of returns on the precious metals under consideration (asymmetry and long memory), proved to have a better predictive accuracy than linear models. Based on MAE and MAPE criteria, no standard GARCH model and no IGARCH and RiskMetrics models were selected on the basis of out-of-sample data.

Results for the twenty-day forecast horizon did not allow for selecting a single best model in terms of lowest mean forecast error, either. The FIAPARCH model was selected for three rates of return (gold spot returns, and gold and silver futures returns). The second selected model was the EGARCH, which was best suited for gold and silver spot returns. Selection of a suitable GARCH model seems, however, to constitute a challenge since there was no definite winner and it is important to realise that the best model may change even for a single type of commodity. This creates an opportunity for arbitrage on the commodity market and requires users to carefully check accuracy of forecasts of a particular model before using it. Next, VaR estimations were performed with the use of in-sample data for the two metals studied with the use of the standard GARCH model and the EGARCH and FIAPARCH models. The results indicate limited abilities of the $\mathrm{GARCH}$ model in terms of long and short trading positions because the null hypothesis was rejected on three levels of significance $(1 \%, 5 \%$ and $10 \%$ ) in the majority of cases following the Kupiec test. The GARCH model seems to be suitable only for gold spot returns. Employing the EGARCH model improves VaR estimation based on in-sample data with respect to silver spot returns (purchase and sale). For the remaining series, the EGARCH model is not better than the standard GARCH.

As for using the FIGARCH model accommodating the asymmetry and long memory effects, it was not possible to reject the null hypothesis for almost all a levels of significance and series of returns based on the Kupiec test. Rejecting the null hypothesis

\begin{tabular}{|c|c|c|}
\hline $\begin{array}{l}\text { Numbe } \\
\text { on gol }\end{array}$ & $\%)$ and estimated dail & tal charges for positions \\
\hline Model & $\begin{array}{c}\text { Number of violations } \\
(\%)\end{array}$ & $\begin{array}{l}\text { Average daily capital charges } \\
\qquad(\%)\end{array}$ \\
\hline \multicolumn{3}{|c|}{ Gold spot returns } \\
\hline GARCH & 0.4217 & 9.32 \\
\hline EGARCH & 0.4217 & 9.37 \\
\hline FIAPARCH & 0.4212 & $\underline{7.94}$ \\
\hline \multicolumn{3}{|c|}{ Gold futures returns } \\
\hline GARCH & 0.9798 & 8.75 \\
\hline EGARCH & 0.8756 & $\underline{7.63}$ \\
\hline FIAPARCH & 0.8756 & 8.62 \\
\hline \multicolumn{3}{|c|}{ Silver spot returns } \\
\hline GARCH & 0.8756 & 17.23 \\
\hline EGARCH & 0.9798 & 18.12 \\
\hline FIAPARCH & 0.9231 & 17.98 \\
\hline \multicolumn{3}{|c|}{ Silver futures returns } \\
\hline GARCH & 0.8756 & 15.43 \\
\hline EGARCH & 0.9798 & 15.29 \\
\hline FIAPARCH & 0.8756 & 15.21 \\
\hline
\end{tabular}


was statistically significant only for the level of significance of $10 \%$. These findings allow for a conclusion that $\mathrm{VaR}$ estimates derived from the FIAPARCH model are more accurate that those derived from the GARCH and EGARCH models in the in-sample period. Additionally, the VaR was estimated for the three abovementioned models with the use of out-ofsample data. Here the results were similar to those from the in-sample tests. The quality of forecasts derived from the GARCH model was better compared to the forecasts based on the in-sample data. The EGARCH model proved to be only slightly better in the out-of-sample period. The FIAPARCH model was better than the remaining models in terms of accuracy of $\mathrm{VaR}$ estimates in the case of short trading positions. The null hypothesis was not rejected in all cases based on the Kupiec test. Accuracy of the FIAPARCH model in terms of forecasts for long trading positions was rejected only for gold futures returns (at the confidence level of $99.5 \%$ and $99.75 \%$ ). All these observations are indicative of the dominant position of the FIAPARCH model in terms of accuracy of VaR forecasts for trading positions with respect to gold and silver as compared to the standard GARCH model and the EGARCH model. This also shows that incorporating the asymmetry and long memory effects in the model improves its predictive ability and results in more precise VaR estimates.

Tab. 7 presents the percentage of empirical number of violations and the average daily capital charges for the period between 1st January 2013 and 31st June 2014. Based on the results of the tests, it was found that the number of violations for each model was not higher than 10, which means that none of them was qualified to the red zone according to Basel II regulations. The average daily capital charges were within the range between $7.94 \%$ (the FIAPARCH model for spot gold) and $18.12 \%$ (the EGARCH model for spot silver) of the portfolio value. In terms of the lowest average daily capital charges, the FIAPARCH model was the best among the three models, with two out of four lowest estimations (for spot gold and silver futures). It is also of importance that in the case of the GARCH model, the lowest daily capital charges for spot silver were observed. Moreover, the GARCH model had a higher average percentage of violations than the FIAPARCH model, which suggests a higher probability (risk of the GARCH model) of entering the red zone according to Basel II regulations.

\section{Conclusions}

As part of the study, as in many other works, one of the latest approaches to the discussed issue was used, which is characterized by attempts to combine in a single model many characteristics of variation. It seems that volatility modeling requires such an approach. For this reason, both symmetry and asymmetry of effects and a long memory of the volatility of commodity prices are checked. Recognizing the long-range dependency in the area of price volatility on commodity markets is very important from the point of view of forecasting, which in turn affects the valuation of assets, the use of hedging and risk management. Therefore, forecasting capabilities are a key element of research on time series, which has a direct impact on decision making. Therefore, in the article, on the basis of the described research process, a model with better predictive capabilities was sought, that is, giving forecasts with a higher degree of accuracy, differently smaller errors. Seven models from the GARCH family were selected for the measurement of predictive capabilities in the research process, which were able to take into account different features of variability in rates of return. The forecasted volatility of gold and silver rate returns for the one-day and twenty-day periods were estimated for the analyzed models. The model that recorded the lowest average forecast errors was typed as the best in terms of predictive capabilities. For example, one-dimensional GARCH models, which allowed for the effect of asymmetry and long memory of time series, showed better prognostic possibilities for the volatility of commodity prices from standard GARCH models. As a result, it was shown that the volatility of the returns on the gold and silver market is better explained by the phenomenon of asymmetry and long memory, which suggests that modeling volatility parameters based on a long memory of time series should contribute to the development of models allowing for more precise forecasting, which has a direct impact on better investment decisions on commodity markets.An analysis of the potential for asymmetry and the effect of long memory relating to return rates and their variability for two main precious metals (gold and silver) 
was made. The research provided evidence for the existence of long-range dependence in the case of daily return rates and volatility for these metals. For the metals tested, the effect of long memory was best captured by the FIGARCH model. The results of the analyses suggest that within the period studied, the FIAPARCH model was the best predictive tool compared to the other models. This stems from the model's ability to satisfactorily capture the effects accompanying price volatility of precious metals, i.e. asymmetry and long memory. Analysing the practical application of the GARCH models and the three best forecasting tools selected, it was found that in the course of VaR estimations, no model achieved the lowest failure rate and the lowest (optimum) capital requirement for all series at the same time. Nevertheless, the FIAPARCH model produced the lowest number of VaR violations (lowest risk of the model) for all series, which means that it seems to be the most advantageous predictive model with respect to gold and silver from the point of view of financial institutions.

Acknowledgement: The project is financed within the framework of the program of the Minister of Science and Higher Education in Poland under the name "Regional Excellence Initiative" in the years 2019-2022, project number $001 / R I D / 2018 / 19$, the amount of financing PLN 10,684,000.00.

\section{References}

Aiolfi, M., \& Timmermann, A. (2006). Persistence of Forecasting Performance and Combination Strategies. Journal of Econometrics, 135(1-2), 31-53. https://dx.doi. org/10.1016/j.jeconom.2005.07.015

Aloui, C., \& Mabrouk, S. (2010). Value-atrisk estimations of energy commodities via long-memory, asymmetry and fat-tailed GARCH models. Energy Policy, 38(5), 2326-2339. https://dx.doi.org/10.1016/j.enpol.2009.12.020

Andersen, T. G., Bollerslev, T., \& Meddahi, N. (2004). Analytic Evaluation of Volatility Forecasts, International Economic Review, 45(4), 1079-1110. https://dx.doi.org/10.1111/ j.0020-6598.2004.00298.x

Arouri, M., Hammoudeh, S., Lahiani, A., \& Nguyen, D. K. (2012a). Long memory and structural breaks in modeling the return and volatility dynamics of precious metals. Quarterly Review of Economics and Finance,
52(2), 207-218. https://dx.doi.org/10.1016/j. qref.2012.04.004

Arouri, M., Lahiani, A., Lévy, A., \& Nguyen, D. K. (2012b). Forecasting the conditional volatility of oil spot and futures prices with structural breaks and long memory models. Energy Economics, 34(1), 283-293. https://dx.doi.org/10.1016/j.eneco.2011.10.015

Assaf, A. (2009). Extreme observations and risk assessment in the equity markets of MENA region: Tail measures and Value-at-Risk. International Review of Financial Analysis, 18(3), 109-116. https://dx.doi.org/10.1016/j. irfa.2009.03.007

Baillie, R., Bollerslev, T., \& Mikkelsen, H. O. (1996). Fractionally Integrated Generalized Autoregressive Conditional Heteroskedasticity. Journal of Econometrics, 74(1), 3-30. https://dx.doi.org/10.1016/S0304-4076(95)01749-6

Basher, S. A., \& Sadorsky, P. (2016). Hedging emerging market stock prices with oil, gold, VIX, and bonds: A comparison between DCC, ADCC and GO-GARCH. Energy Economics, 54, 235-247. https://dx.doi. org/10.1016/j.eneco.2015.11.022

Baur, D. G., \& Lucey, B. M. (2010). Is gold a hedge or a safe haven? An analysis od stocks, bonds and gold. The Financial Review, 45(2), 217-229. https://dx.doi.org/10.1111/j.15406288.2010.00244.x

Baur, D. G., \& McDermott, T. K. (2010). Is gold a safe have? An international evidence. Journal of Banking \& Finance, 34(8), 1886-1898. $\quad$ https://dx.doi.org/10.1016/j. jbankfin.2009.12.008

Bekaert, G., \& Wu, G. (2000). Asymmetric volatility and risk in equity markets. The Review of Financial Studies, 13(1), 1-42. https://dx.doi. org/10.1093/rfs/13.1.1

Bodington, L., \& Seetharam, Y. (2015). Gold in a South African Market: A Safe Haven or Hedge? Applied Economics Quarterly, 61(4), 331-352. https://dx.doi.org/10.3790/ aeq.61.4.331

Cheng, W. H., \& Hung, J. C. (2011). Skewness and leptokurtosis in $\mathrm{GARCH}$ typed VaR estimation of petroleum and metal asset returns. Journal of Empirical Finance, 18(1), 160-173. https://dx.doi.org/10.1016/j. jempfin.2010.05.004

Choi, K., \& Hammoudeh, S. (2009). Long memory in oil and refined products markets. Journal of Energy, 30(2), 97-116. https://dx.doi. org/10.5547/ISSN0195-6574-EJ-Vol30-No2-5 
Doman, M., \& Doman, R. (2009). Volatility and risk modeling. Methods of financial econometrics. Warsaw: Wolters Kluwer.

Elder, J., \& Serletis, A. (2008). Long memory in energy futures prices. Review of Finance and Economics, 17(2), 146-155. https://dx.doi. org/10.1016/j.rfe.2006.10.002

Engle, R. F. (1982). Autoregressive conditional heteroscedasticity with estimates of the variance of UK inflation. Econometrica, 50(4), 987-1008. https://dx.doi.org/10.2307/1912773

Furió, D., \& Climent, F. J. (2013). Extreme value theory versus traditional GARCH approaches applied to financial data: a comparative evaluation. Quantitative Finance, 13(1), 45-63. https://dx.doi.org/10.1080/14697 688.2012.696679

Geweke, J., \& Porter-Hudak, S. (1983). The estimation and application of longmemory time series models. Journal of Time Series Analysis, 4(4), 221-238. https://dx.doi. org/10.1111/j.1467-9892.1983.tb00371.x

Hammoudeh, S., \& Yuan, Y. (2008). Metal volatility in presence of oil and interest rate shocks. Energy Economics, 30(2), 606-620. https://dx.doi.org/10.1016/j.eneco.2007.09.004

Hammoudeh, S., Yuan, Y., McAleer, M., \& Thompson, M. (2010). Precious metalsexchange rate volatility transmissions and hedging strategies. International Review of Economics \& Finance, 19(4), 633-647. https://dx.doi.org/10.1016/j.iref.2010.02.003

Iwaszczuk, N., \& Orłowska-Puzio, J. (2015). Hedging impast on the development of foreign trade operators. Economic Studies. Scientific Paper of the University of Economics in Katowice, 214, 51-63.

Jajuga, K. (2016). From duration analysis to GARCH models - An approach to systematization of quantitative methods in risk measurement. Economics and Business Review, 2(16), 7-19. https://dx.doi. org/10.18559/ebr.2016.3.2

Jorion, P. (2007). Value at Risk. New York, NY: McGraw-Hill.

Kang, S. H., \& Yoon, S. M. (2013). Modeling and forecasting the volatility of petroleum futures prices. Energy Economics, 36, 354-362. https://dx.doi.org/10.1016/j.eneco.2012.09.010

Kasprzak-Czelej, A. B. (2015). Gold investments as a hedge against inflation in Poland. Annales Universitatis Mariae CurieSklodowska Lublin - Polonia, XLIX(4), 205-214.
Kupiec, P. (1995). Technique for verifying the accuracy of risk measurement models. Journal of Derivatives, 3(2), 73-84. https://dx.doi.org/10.3905/jod.1995.407942

Lama, A., Jha, G. K., Paul, R. K., \& Gurung, B. (2015). Modelling and Forecasting of Price Volatility: An application of GARCH and EGARCH Models. Agricultural Economics Research Review, 28(1), 73-82. https://dx.doi. org/10.5958/0974-0279.2015.00005.1

Mamcarz, K. (2015). Long-term determinants of the price of gold. Economic Studies. Scientific Paper of the University of Economics in Katowice, Contemporary Finance, 4(252), 80-94.

Mckenzie, M. D., Mitchell, H., Brooks, R. D., \& Faff, R. W. (2001). Power ARCH modelling of commodity futures data on the London Metal Market. European Journal of Finance, 7(1), 22-38. https://dx.doi. org/10.1080/13518470123011

Miciuła, I. (2014). The concept of FTS analysis in forecasting trends of exchange rate changes, Economics \& Sociology, 7(2), 172-182. https://dx.doi.org/10.14254/2071789X.2014/7-2/14

Miciuła, I. (2015). The Universal Elements of Strategic Management of Risks in Contemporary Enterprises. Entrepreneurship and management, 16(8), 313-322.

Miciuła, I. (2018). Methods of Creating Innovation Indices Versus Determinants of Their Values. Eurasian Economic Perspectives. Eurasian Studies in Business and Economics, 8(2), 357-366. https://dx.doi.org/10.1007/9783-319-67916-7_23

Mikita, M. (2016). Future internationl monetary system. Optimum. Economic studies, 1(79), 85-99. https://dx.doi.org/10.15290/ ose.2016.01.79.06

Mohammadi, H., \& Su, L. (2010). International evidence on crude oil price dynamics: applications of ARIMA-GARCH models. Energy Economics, 32(5), 1001-1008. https://dx.doi.org/10.1016/j.eneco.2010.04.009

Moskal, A., \& Zawadzka, D. (2014). Investment in gold as an example of alternative investment - in the context of capital market in Poland. Economics and Management, 3, 330-343. https://dx.doi.org/10.12846/j. em.2014.03.23

Nielsen, M., \& Sørensen, T. (2015). Has Gold lost its Safe-Haven Property? Aarhus: Economics and Business Economics. 
Pedersen, C. S., \& Satchell, S. E. (1998). An Extended Family of Financial Risk Measures. The Geneva Papers on Risk and Insurance Theory, 23(2), 89-117. https://doi. org/10.1023/A:1008665926432

Potrykus, M. (2015). Investment in gold safe haven, security, or source of diversification for a Polish investor. Science of Finance, 3(24), 193-207.

RiskMetrics. (1996). RiskMetrics - Technical Document. New York, NY: J. P. Morgan.

Robinson, P. M. (1995). Log-periodogram regression of time series with long range dependence. Annals of Statistics, 23(3), 1048-1072. https://dx.doi.org/10.1214/ aos $/ 1176324636$

Stock, J. H., \& Watson, M. (2004). Combination Forecasts of Output Growth in Seven-Country Data Set. Journal of Forecasting, 23(6), 405-430. https://dx.doi. org/10.1002/for.928

Szczerbak, G. (2017). The use of GARCH models in the analysis of the financial risk of joint-stock companies listed on the GPW. Optimum. Economic studies, 3(87), 176-194.

Tarczyński, W., \& Mojsiewicz, M. (2001). Risk management. Warsaw: PWE.

Tayefi, M., \& Ramanathan, T. V. (2012). An overview of FIGARCH and Related Time Series Models. Austrian Journal of Statistics, 41(3), 175-196. https://dx.doi.org/10.17713/ ajs.v41i3.172

Thuraisamy, K. S., Sharma, S. S., \& Ahmed, H. J. A. (2013). The relationship between Asian equity and commodity futures markets. Journal of Asian Economics, 28, 67-75. https://dx.doi. org/10.1016/j.asieco.2013.04.003

Timmerman, A. (2006). Forecast Combinations. In Handbook of Economic Forecasting (Vol. 1, pp. 135-196). Amsterdam: Elsevier.

Vivian, A., \& Wohar, M. E. (2012). Commodity volatility breaks. Journal of International Finance Market, Institutions and Money, 22(2), 395-422. https://dx.doi. org/10.1016/j.intfin.2011.12.003

Wang, Y., Wu, C., \& Wei, Y. (2011). Can GARCH-class models capture long memory in WTI crude oil markets? Econometric Models, 28(3), 921-927. https://dx.doi.org/10.1016/j. econmod.2010.11.002

Wei, Y., Wang, Y., \& Huang, D. (2010). Forecasting crude oil market volatility: further evidence using GARCH-class models. Energy Economics, 32(6), 1477-1484. https://dx.doi. org/10.1016/j.eneco.2010.07.009

Wilhelmsson, A. (2006). GARCH Forecasting Performance under Different Distribution Assumptions. Journal of Forecasting, 25(8), 561-578. https://dx.doi. org/10.1002/for.1009

Xekalaki, E., \& Degiannakis, S. (2010). Arch models for financial applications. Chichester: Wiley.

Zivot, E., \& Andrews, D. W. K. (1992). Further evidence on the great crash, the oil price shock, and the unit root hypothesis. Journal of Business \& Economic Statistics, 10(3), 251-270. https://dx.doi.org/10.1080/073 50015.1992.10509904 